\title{
NITROGEN FERTILIZERS TECHNOLOGIES FOR COFFEE PLANTS
}

\author{
Wantuir Filipe Teixeira Chagas ${ }^{1}$, Douglas Ramos Guelfi Silva², Jordana Reis Lacerda ${ }^{3}$, \\ Leandro Campos Pinto ${ }^{4}$, André Baldansi Andrade ${ }^{5}$, Valdemar Faquin ${ }^{6}$
}

(Received: October 02, 2018; accepted: November 19, 2018)

\begin{abstract}
The application of urea in coffee crop has caused high losses of nitrogen $(\mathrm{N})$ by volatilization, causing low use and recovery of this nutrient. This low use of $\mathrm{N}$ may interfere in the growth and nutrition of the coffee crop and thus, influence the efficiency of the nitrogen fertilization. The aim in this work was to assess the growth, nutritional and physiological characteristics and the agronomic efficiency of the nitrogen fertilization with different nitrogen fertilizer technologies. The experiment was performed in a greenhouse in pots with a volume of $14 \mathrm{~L}$. In each pot, it was performed the transplanting of two plants of coffee. The experimental design was entirely randomized, with four replicates. The following nitrogen fertilizers were applied in the dose of $10 \mathrm{~g} \mathrm{pot}^{-1}$, devided into three applications with interval of 50 days: Conventional urea; ammonium nitrate; urea + formaldehyde; Polyblen Extend ${ }^{\circledR}$; Polyblen Montanha ${ }^{\circledR}$; Urea + polyurethane; urea + plastic resin; ammonium sulfate $+\mathrm{CaCO}_{3}$ and the control, without $\mathrm{N}$ application. After cropping, it was evaluated the growth, nutritional and physiological parameters. Afterward, it was calculated two agronomic efficiency index of the nitrogen fertilization. The highest values of plants height, the total dry mass of plants and leaf area in coffee seedlings were found with the application of Polyblen Extend ${ }^{\circledR}$. This blend also provided higher accumulation of $\mathrm{N}$ in the leaf and the whole plant. The application of Polyblen Extend ${ }^{\circledR}$ provided higher agronomic efficiency and also enhanced the photosynthetic rate in the coffee plants.
\end{abstract}

Index terms: Coffea arabica, agronomic efficiency, nitrogen fertilization.

\section{TECNOLOGIAS DE FERTILIZANTES NITROGENADOS PARA PLANTAS DE CAFÉ}

RESUMO: O baixo aproveitamento do $\mathrm{N}$ pode interferir no crescimento e na nutrição do cafeeiro e com isso influenciar a eficiência da adubação nitrogenada. Neste sentido, objetivou-se com este trabalho avaliar as características de crescimento, nutricionais, fisiológicas e a eficiência agronômica da adubação nitrogenada com diferentes tecnologias de fertilizantes nitrogenados. O experimento foi realizado em casa de vegetação em vasos com volume de $14 \mathrm{~L}$. Em cada vaso foi realizado o transplantio de duas mudas de café. O delineamento foi inteiramente ao acaso, com quatro repetições. Os seguintes fertilizantes nitrogenados foram aplicados na dose de $10 \mathrm{~g} \mathrm{vaso}^{-1}$ de $\mathrm{N}$, parceladas em três aplicações com intervalo de 50 dias. As fontes de N foram: Ureia convencional; Nitrato de Amônio; Ureia + formaldeído; Polyblen Extend ${ }^{\circledR}$; Polyblen Montanha ${ }^{\circledR}$; Ureia + Poliuretano; Ureia + resina plástica; Sulfato de Amônio $+\mathrm{CaCO}_{3}$ e o controle, sem aplicação de N. Após o cultivo, foram avaliados os parâmetros de crescimento, nutricionais e fisiológicos nas plantas de café. Posteriormente foram calculados dois índices de eficiência agronômica da adubação nitrogenada. Os maiores valores de altura de plantas, massa seca total de plantas e área foliar foram encontrados com a aplicação do Polyblen Extend ${ }^{\circledR}$. Este Blend também proporcionou maior acúmulo de $\mathrm{N}$ na folha e na planta inteira. A aplicação do Polyben Extend ${ }^{\circledR}$ promoveu maior eficiência agronômica e aumentou a taxa fotossintética no cafeeiro.

Termos para indexação: Coffea arabica, eficiência agronômica, adubação nitrogenada.

\section{INTRODUCTION}

Among the nitrogen fertilizers most used in coffee cultivation, urea is the most prominent. The use of this fertilizer has advantages such as lower cost per unit of $\mathrm{N}$, high $\mathrm{N}$ concentration, low production cost, low corrosivity and lower acidifying power compared to other $\mathrm{N}$ sources (MARCHESAN et al., 2011).

However, the reaction of urea's hydrolysis in the soil causes an increase of the $\mathrm{pH}$ in the region of the granule (DOMINGHETTI et al., 2016). This alkaline $\mathrm{pH}$ environment hinders the passage of ammonia $\left(\mathrm{NH}_{3}\right)$ to ammonium $\left(\mathrm{NH}_{4}^{+}\right)$by the absence of protons $\left(\mathrm{H}^{+}\right.$ions), which concentrate ammonia in this region and increase the loss by volatilization of $\mathrm{N}-\mathrm{NH}_{3}(\mathrm{CHAGAS}$ et al., 2016). These losses contribute to a decrease in nitrogen fertilizer efficiency and can reach values up to $40 \%$ of the total $\mathrm{N}$ that is applied (FARIA et al., 2014).

Currently, one of the most studied practices to improve the efficiency of nitrogen fertilizers is the use of increased efficiency's fertilizers, classified as stabilized, slow release and controlled release (AZEEM et al., 2014; CHIEN et al., 2009).

Stabilized fertilizers are those having the addition of urease inhibitors and/or nitrification. Among the stabilized group, NBPT [N- (n-butyl)] thiophosphorictriamide is the most widely used

1,2,3,4,5,6Universidade Federal de Lavras/UFLA - Departamento de Ciência do Solo/DCS - Cx. P. 3037 - $37.200-000$ Lavras- MG- wantuirfilipe@gmail.com, douglasguelfi@dcs.ufla.br, jordanarlacerda@hotmail.com, leandcampos@yahoo.com.br, andre.batp@hotmail.com, vafaquin@dcs.ufla.br 
urease inhibitor worldwide (SANZ-COBENA et al., 2012). However, there is still a need for more studies, especially in regions with a tropical climate, such as Brazil. This is justified because the NBPT urease inhibitory activity may decrease with increasing soil temperature (ABALOS et al., 2014).

Slow-release nitrogen fertilizers are products of the condensation of urea with aldehydes. Among the most commonly used is formaldehyde urea (GUELFI, 2017). These fertilizers promote the reduction of the solubility of the $\mathrm{N}$ fractions present in the composition of the urea molecule (GUELFI, 2017).

On the other hand, adding compounds that cover the fertilizer granule produce the controlled release fertilizers which reduce direct exposure to water and air, and slowly release the nutrient into the soil solution (TRENKEL, 2010). In this group, are highlighted those coated with sulfur, sulfur and polymers or only by the polymer (DOMINGHETTI et al., 2016).

Several authors studied these fertilizers, such as Pereira et al. (2009) and Frazão et al. (2014) in the maize cultivation and Garcia et al. (2011) in coffee. Pereira et al. (2009) and Frazão et al. (2014) found higher yields of maize with the application of Urea+NBPT compared to conventional urea application. Garcia et al. (2011), when evaluating the dry mass of coffee after 285 days of conventional urea and NBPT application, found a higher dry mass with Urea+NBPT application.

However, the factor that most limits the use of these fertilizers is the cost, which is higher when compared to conventional nitrogen fertilizers (GUELFI, 2017). An alternative to reduce the costs of these fertilizers is the use of "Blends" (a physical mixture of fertilizers). With the use of "Blends", it is sought to use these technologies in an integrated way with conventional fertilizers and with this, to reduce costs compared to the exclusive use of fertilizers of increased efficiency (TRENKEL, 2010). In addition, can be created an adjustment of the N-release curve for each cultivation. According to Noellsch et al. (2009), the conventional fertilizer (with high solubility in water) can provide the initial demand for $\mathrm{N}$ by the cultivation and the controlled fertilizer release over a longer period.

In this context, the aim of this work was to assess the growth, nutritional and physiological characteristics and the agronomic efficiency of the nitrogen fertilization with different nitrogen fertilizer technologies.

\section{MATERIAL AND METHODS}

The experiment was carried out in a greenhouse of the Department of Soil Science of the Federal University of Lavras (UFLA), in Lavras city, Minas Gerais, from June 2015 to January 2016. It was used a soil of clay texture, classified as Red Latosol (RL) (SANTOS et al., 2013) collected in the B horizon, in Lavras. The collected soil was air-dried, passed in a sieve with a $4 \mathrm{~mm}$ opening, homogenized and placed in the pots. Concomitantly, soil samples were collected and used for chemical and physical characterization (Table 1), according to Comissão de Fertilidade do Solo do Estado de Minas Gerais - CFSEMG (1999).

Soil $\mathrm{pH}$ was determined in water, in the soil: water ratio of $1: 2,5 ; \mathrm{H}+\mathrm{Al}($ Method $\mathrm{Ca}$

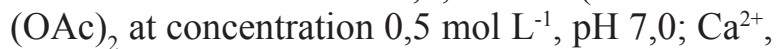
$\mathrm{Mg}^{2+}$ and $\mathrm{Al}^{3+}$ exchangeable, $\mathrm{KCl}$ were extracted with $1 \mathrm{~mol} \mathrm{~L}^{-1}$ and determined by titulometry; $\mathrm{P}$ and $\mathrm{K}$ were extracted by Mehlich-1 and analyzed by colorimetry $(\mathrm{P})$ and flame photometry $(\mathrm{K})$; the organic carbon was determined by oxidation with potassium dichromate; $\mathrm{Zn}, \mathrm{Mn}$, and $\mathrm{Cu}$ were extracted by Mehlich-1 and determined by atomic absorption spectrophotometry. The values of effective CTC (t); CTC at pH 7.0 (T), the sum of bases (SB) and percentages of saturation by bases $(\mathrm{V} \%)$ and by aluminum ( $\mathrm{m} \%)$, were obtained indirectly, using the values of potential acidity, exchangeable bases, and exchangeable aluminum (CFSEMG, 1999).

It was used a completely randomized design with treatments composed of nitrogen fertilizers: Conventional urea, Ammonium Nitrate, Urea + Formaldehyde, Polyblen Extend ${ }^{\circledR}$, PolyblenMontanha ${ }^{\circledR}$, Urea + Polyurethane, Urea + Plastic Resin, Ammonium Sulfate $+\mathrm{CaCO}_{3}$, and the Treatment control (without the addition of $\mathrm{N}$ ) with four replicates.

Fertilizers' characteristics are: of $\mathrm{N}$;

1) Conventional urea - Granular with $45 \%$

2) Ammonium Nitrate - Granular with 30\% of $\mathrm{N}$;

3) Urea + formaldehyde - It has $26 \%$ of $\mathrm{N}$ and is obtained by reaction between formaldehyde $\left(\mathrm{H}_{2} \mathrm{CO}\right)$ molecules with large amounts of urea, under controlled manufacturing conditions, resulting in a mixture of methylated urea chains of different sizes, gradually released to the soil by the action of microorganisms that decompose the chain. 
TABLE 1 - Chemical and granulometric characteristics of the B horizon of the Red Latosol.

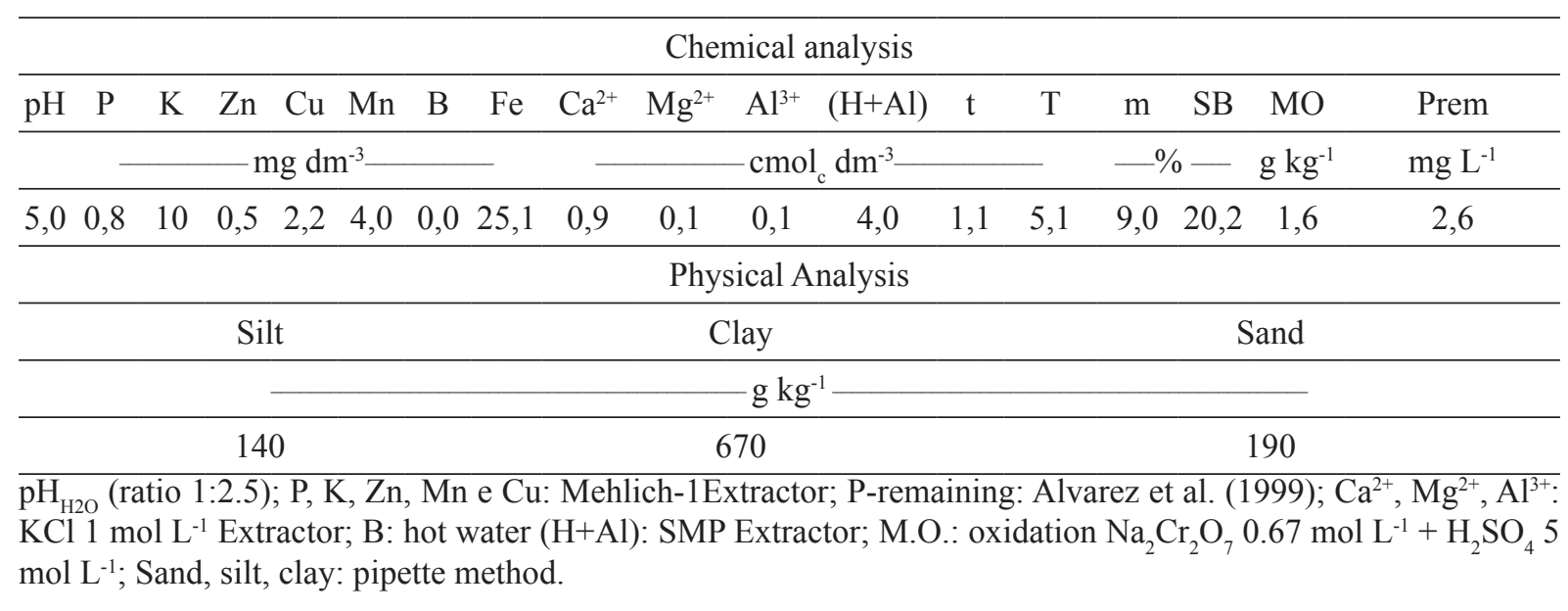

4) Polyblen Extend ${ }^{\circledR}$-Sulfur-coated (S) urea Blends + polymers $(70 \%)$ and conventional urea + NBPT (30\%): Urea coated with an elemental sulfur layer plus an organic polymer and granular urea + NBPT (uncoated). The total nitrogen content is $39 \%$, with $12 \%$ elemental sulfur.

5) Polyblen Montanha ${ }^{\circledR}$-Sulfur-coated (S) urea Blends + polymers $(70 \%)$ and conventional urea + NBPT (30\%). Urea coated with elemental sulfur plus an organic polymer and granular urea + NBPT (uncoated). The total of $\mathrm{N}$ content is $39 \%$, with $12 \%$ elemental sulfur. Polyblen Montanha ${ }^{\circledR}$ differs from Polyblen Extend ${ }^{\circledR}$ because it has a greater thickness of the coating layer (CHAGAS et al., 2016).

6) Urea + Polyurethane - It has $40 \%$ of $\mathrm{N}$ and $2 \%$ of $\mathrm{K}_{2} \mathrm{O}$. Polyurethane coats the urea.

7) Urea + plastic resin - It has $39 \%$ of $\mathrm{N}$. The urea is coated by plastic resin, which allows the contact of water with urea according to its degradation by the action of temperature and soil moisture.

8) Ammonium Sulfate $+\mathrm{CaCO}_{3}-$ Contains $29 \%$ of $\mathrm{N}, 7 \%$ of $\mathrm{S}, 5 \%$ of $\mathrm{Ca}$ and $2 \%$ of $\mathrm{Mg}$. Contains $\mathrm{N}$ in the amide and ammoniacal forms associated with marine calcium carbonate $\left(\mathrm{CaCO}_{3}\right)$.

The experimental unit was formed by pot filled with $14 \mathrm{~kg}$ of soil and two coffee seedlings (Coffea arabica L., Cultivar Acaia IAC 474-19), produced from sowing in the washed sand and sieved with four months of age (after present the second pair of true leaves).

Before the transplanting of the seedlings, liming was performed to raise the saturation by bases to $70 \%$ (CFSEMG, 1999). The limestone used was formed by the mixture of calcium carbonate and magnesium carbonate (P.A), passing through a period of incubation of 30 days. $4,56 \mathrm{~g}$ pot $^{-1}$ of calcium and $1,11 \mathrm{~g}$ pot $^{-1}$ of magnesium were applied.

Subsequently, fertilization with $20 \mathrm{~g}$ of $\mathrm{P}_{2} \mathrm{O}_{5}$ $+6,72 \mathrm{~g}$ of $\mathrm{K}_{2} \mathrm{O}$ pot $^{-1}$ according to Chagas et al (2016), using triple superphosphate and potassium chloride as sources, was carried out which were homogenized to the soil on $06 / 22 / 2015$. After that, the coffee plants were transplanted (two plants per pot), with pruning of the apical region of the root system.

The dose of $\mathrm{N}$ applied for each fertilizer was $10 \mathrm{~g} \mathrm{pot}^{-1}$ of $\mathrm{N}$, according to Chagas et al (2016), divided into three applications with an interval of 50 days. The first application was performed after 40 days of transplanting.

During the whole period of the experiment, the soil moisture was maintained at $60 \%$ of the total pore volume (TPV), by weighing the pot and adding deionized water. At 60 days after transplanting, foliar fertilization with $0,3 \%$ of $\mathrm{B}$ and $0,3 \%$ of $\mathrm{Zn}$ applied in the form of boric acid and zinc sulfate, as recommended by Garcia (2011).

At the end of the experiment (six months after transplanting), were evaluated height $(\mathrm{PH})$ and plant diameter (PD). The photosynthetic rate was measured on the day of the experiment, in the morning between 9:00 am and 11:00 am, in fully expanded leaves of the middle third of the plants, with the aid of Infra-Red Gas Analyzer (IRGA) model 266 LI6400-XT.

The relative chlorophyll index (RCI) was also calculated on the day of the experiment, 
by reading with the chlorophyll meter SPAD502 (Soil and Plant Analysis Development). The reading was performed in the middle third of the leaf, sampled in the middle part of the plant. Four readings per plant were carried out in the two experimental plot plants. Before carrying out the readings, the reading tester calibrated the instrument, according to the recommendations in the manual.

After these evaluations, the leaves were removed for determination of the leaf area (LA) with the aid of the Li-color leaf area integrator, model LI 3100.

Afterward, the plants were removed from the pots and, with the help of tap water, the shoot and roots were washed in sieves and then packed in paper bags and dried at $75^{\circ} \mathrm{C}$ in a forced circulation oven until constant weight to determine the weight of the dry mass. Then, the dry mass was ground, and samples equivalent to two grams were removed, which were submitted to nitroperchloric digestion followed by determination of the $\mathrm{N}$ content, according to Tedesco et al. (1995). The product between the dry weight and the $\mathrm{N}$ content in each part of the coffee plants determined the $\mathrm{N}$ accumulation.

After obtaining these data, the following efficiency indices of the nitrogen fertilization were calculated:

a) Relative agronomic efficiency index $($ RAEI $)=[$ (total dry mass of the source tested, $\left.\mathrm{g} \mathrm{pot}^{-1}\right)$ - (total dry mass of control, $\mathrm{g}_{\text {pot }}{ }^{-}$ $\left.{ }^{1}\right) /\left(\right.$ total dry mass of urea, g pot $\left.^{-1}\right)-($ total dry mass of control, $\left.\left.\mathrm{g} \mathrm{pot}^{-1}\right)\right]$ x 100 .

b) Agronomic Efficiency of Applied $\mathrm{N}(\mathrm{AE})=$ (total dry mass of the source tested, $g$ pot $\left.^{-1}\right)$ - (total dry mass of control, g pot $\left.{ }^{-1}\right) /$ Dose of $\mathrm{N}$ applied, in $\mathrm{g} \mathrm{pot}^{-1}$ (FAGERIA; SANTOS; MORAES, 2010).

All data were submitted to analysis of variance (ANOVA) and means were compared by the Skott Knott test $(\mathrm{a}=0,05)$. ANOVA was performed after checking for normality (Shapiro-Wilk'stest) and homogeneity of variance (Bartlett's Test) of the data. Statistical analyzes were performed using the SISVAR $5.3^{\circledR}$ statistical analysis program (FERREIRA, 2011).

\section{RESULTS AND DISCUSSION}

The Plant height, stem diameter, leaf dry mass, dry mass of roots, dry root mass and total dry mass of plants were significantly influenced $(p \leq 0,05)$ by treatments with nitrogen fertilizers.
For all the $\mathrm{N}$ sources applied, there was an increase in plant height compared to the control treatment (Figure 1a).

The highest value of plant height was 55 $\mathrm{cm}$ with the application of Polyblen Extend ${ }^{\circledR}$, it was an increase of $4 \mathrm{~cm}$ in comparison to the treatment with ammonium nitrate, and of $12 \mathrm{~cm}$ in comparison to the application of urea. The other fertilizers presented no differences in comparison to urea. The lowest height value was $23 \mathrm{~cm}$ in the control treatment (without application of $\mathrm{N}$ ).

The lowest stem diameter value was $4 \mathrm{~mm}$ also in the control treatment. With the application of nitrogen fertilizers there was an increase in comparison to the control treatment, but no difference was found between the fertilizers (Figure 1b).

The minimum value of stem height and diameter found in the control treatment corroborate with the results found by Clemente et al. (2008). These authors studied critical bands of $\mathrm{N}$-content in the coffee tree in post-planting and found lower height $(50 \mathrm{~cm})$ and stem diameter $(3 \mathrm{~mm})$ in the control treatment after 270 days of transplanting the seedlings. According to Fenilli et al. (2008), N is the main responsible for the vegetative growth in the coffee tree.

The increased height of $8 \%$ and $23 \%$ with the application of Polyblen Extend ${ }^{\circledR}$, when compared to the application of ammonium nitrate and to the average of the other nitrogen fertilizers, respectively, may be associated to lower $\mathrm{N}$ losses due to volatilization of ammonia and also to the supply time of $\mathrm{N}$.

Polyblen Extend ${ }^{\circledR}$ has lower loss of $\mathrm{N}-\mathrm{NH}_{3}$ compared to urea and can also provide $\mathrm{N}$ for a longer period than ammonium nitrate (soluble fertilizer) (CHAGAS et al., 2016). The part of urea treated with NBPT is soluble, less susceptible to losses by volatilization and meets the immediate demand of $\mathrm{N}$ by the culture (CANCELLIER et al., 2016). And the urea fraction coated with $S^{0}+$ polymers releases the $\mathrm{N}$ gradually in the medium and long term (NOELLSCH et al., 2009).

The dry leaf mass had a maximum value of $66,1 \mathrm{~g} \mathrm{pot}^{-1}$ with the application of Polyblen Extend $^{\circledR}$, while the minimum value was $27,3 \mathrm{~g} \mathrm{pot}^{-}$ ${ }^{1}$ in the control treatment (Figure 2a).

For the dry mass of branches (Figure 2b) and roots (Figure 2c), the minimum values were 20,2 and 3,4 $\mathrm{g} \mathrm{pot}^{-1}$, respectively, found in the control treatment. Among the nitrogen fertilizers, there were no significant differences. 


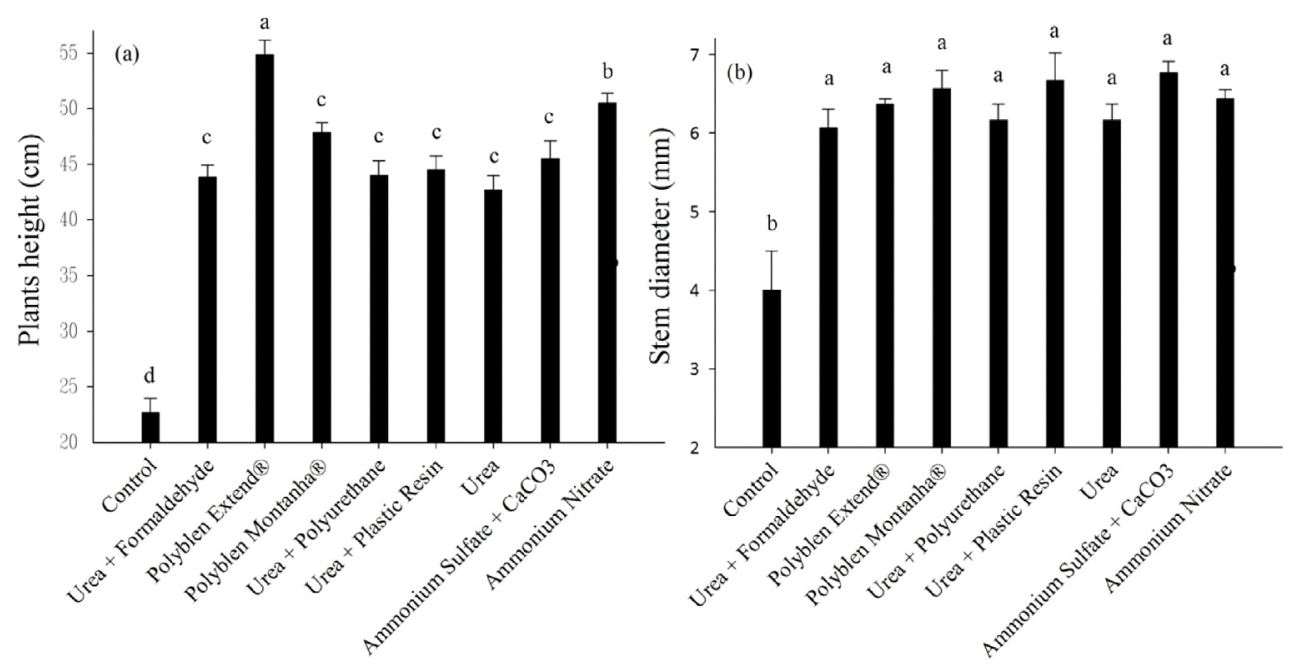

FIGURE 1 - Plants height (1a) and stem diameter (1b) of the coffee plants after application of nitrogen fertilizers. Values followed by the same letter belong to the same cluster by the Skott-Knott test at 5\% probability. The vertical bars represent the standard error of the averages $(n=3)$.

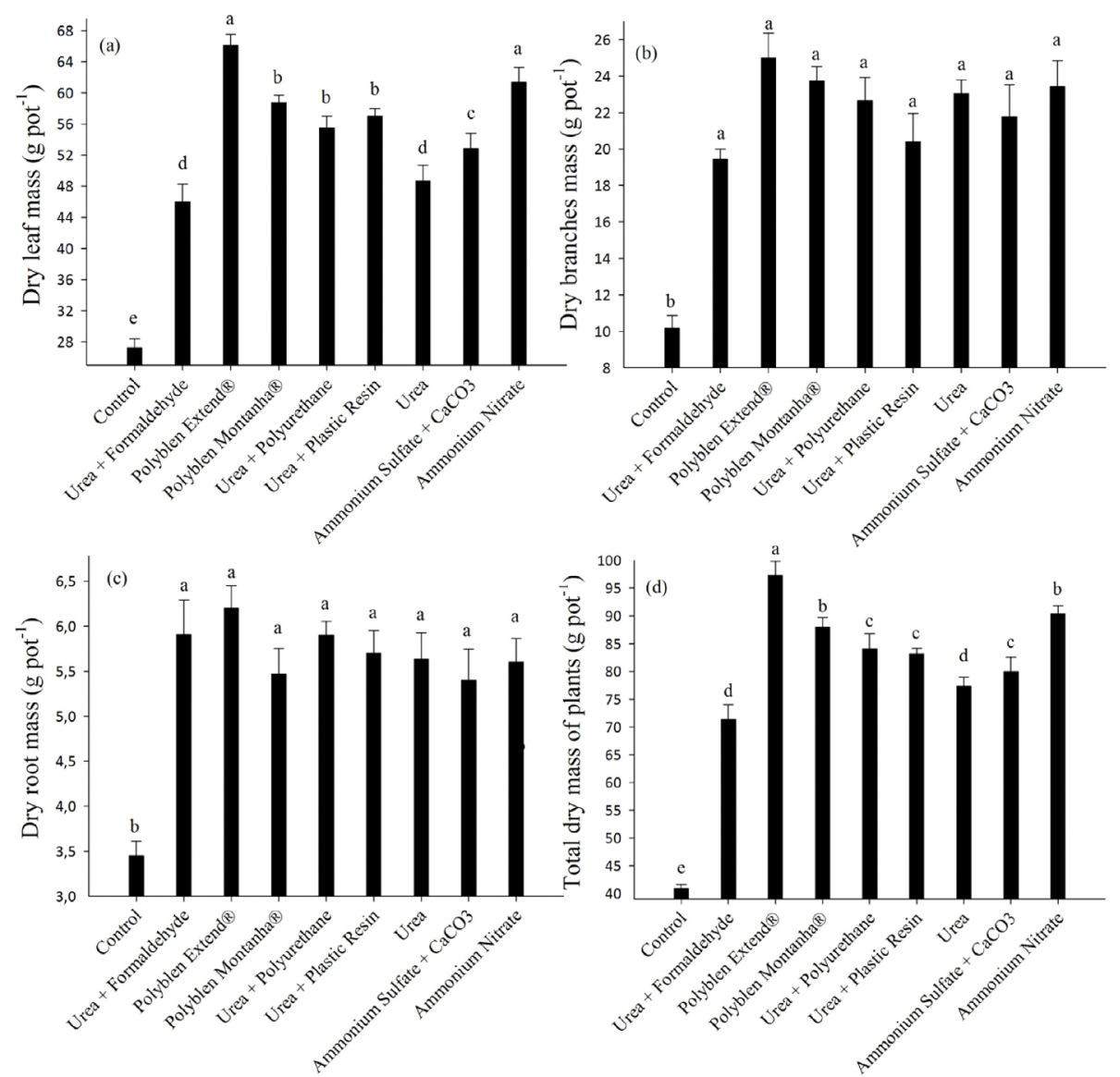

FIGURE 2 - Dry leaf mass, dry mass of branches, dry root mass and total dry mass of coffee plants after the application of nitrogen fertilizers. Values followed by the same letter belong to the same cluster by the Skott-Knott test at $5 \%$ probability. The vertical bars represent the standard error of the averages $(n=3)$. 
The maximum value of the total dry mass of plants occurred with the application of Polyblen Extend $^{\circledR}$ and was equal to 97,3 g pot $^{-1}$, while the minimum value was $40,9 \mathrm{~g} \mathrm{pot}^{-1}$ in the control treatment (Figure 2d).

With the application of urea, the dry mass was $77,3 \mathrm{~g} \mathrm{pot}^{-1}$. The increase in total dry mass of plants with the application of Polyblen Extend ${ }^{\mathbb{B}}$ was $20,6 \%$ compared to the treatment with urea application. These results confirm those found by Garcia et al. (2011), who, when studying the effect of urea with urease inhibitor on the growth of coffee tree seedlings, concluded that the use of NBPT associated with urea promotes an $18 \%$ gain in dry mass production of plants. The authors evaluated the dry mass of coffee after 285 days of conventional urea and Urea+NBPT application.

Possibly, this gain is due to the reduction of $\mathrm{N}$ losses by volatilization, since the coating of the fertilizer with S and the urease inhibitor (NBPT) decreases the rate of hydrolysis of urea, which allows better utilization of nitrogen. The coating of polymer urea causes less amount of urea to be hydrolyzed at one time, and this prevents the accumulation of $\mathrm{N}_{-} \mathrm{NH}_{4}^{+}$in the soil, thereby reducing the risk of $\mathrm{N}^{-\mathrm{NH}_{3}}$ formation (PENG et al., 2015).

According to Carelli etal.(2006), an adequate supply of $\mathrm{N}$ promotes a quick development of the coffee tree, specifically through the increase in the number of pairs of leaves per plant. This increase, associated with other factors such as the number of nodes per branch, number of fruiting nodes and flowers per node, is responsible for the higher yields of the coffee tree (CARELLI et al., 2006; NAZARENO et al., 2003).

Martins et al. (2014), evaluating the dry mass of the aerial part of the maize after the application of conventional urea and polymer coated urea, did not find differences between the sources when they were applied during the rainy season. However, in another crop, where the fertilizers were applied under a drying condition after fertilization, the authors found a higher dry shoot mass with the application of polymer coated urea when compared to conventional urea.

The leaf area was significantly influenced $(p \leq 0,05)$ by the treatments with nitrogen fertilizers and the control treatment (Figure 3 ).

Leaf area pot $^{-1}$ followed the descending order for nitrogen fertilizer treatments: Polyblen Extend ${ }^{\circledR}$ $\left(2195,8 \mathrm{~cm}^{2}\right)>$ Ammonium Nitrate $\left(2010,6 \mathrm{~cm}^{2}\right)$ $=$ PolyblenMontanha $^{\circledR}\left(1906,8 \mathrm{~cm}^{2}\right)>$ Urea + Polyurethane $\left(1771,1 \mathrm{~cm}^{2}\right)=$ Ammonium Sulfate + $\mathrm{CaCO}_{3}\left(1758,9 \mathrm{~cm}^{2}\right)>$ Urea + Plastic Resin $(1626,9$ $\left.\mathrm{cm}^{2}\right)=$ Urea + Formaldehyde $\left(1590,0 \mathrm{~cm}^{2}\right)=$ Urea $\left(1585,9 \mathrm{~cm}^{2}\right)>$ Control $\left(538,5 \mathrm{~cm}^{2}\right)$.

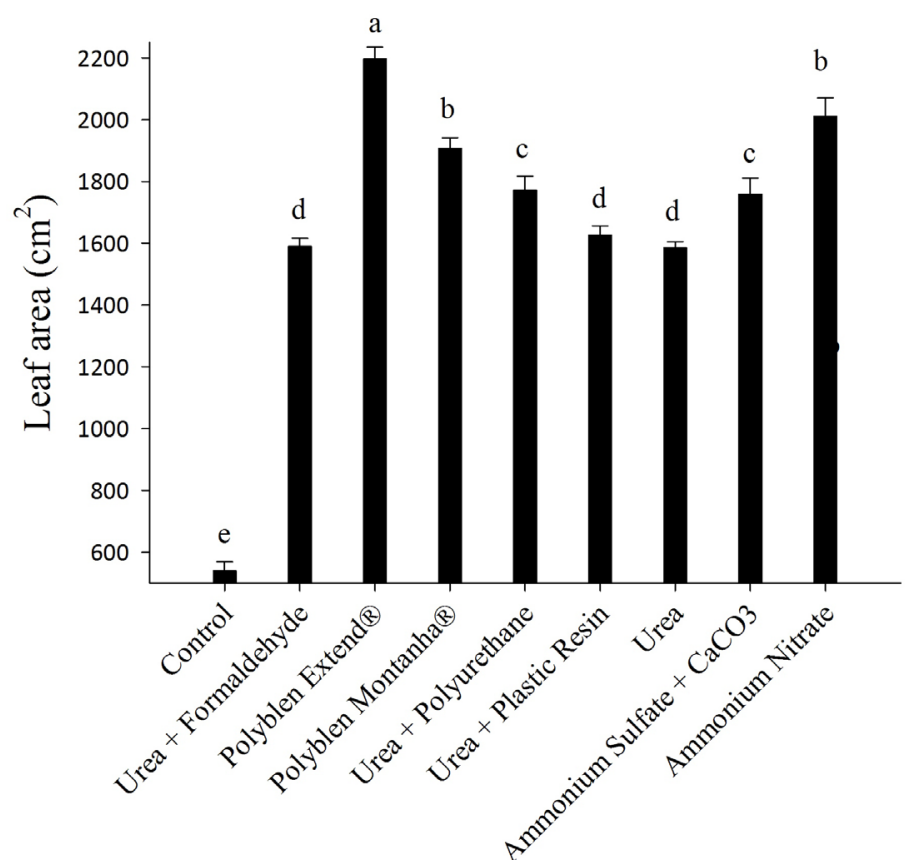

FIGURE 3 - Leaf area pot $^{-1}$ of coffee seedlings after nitrogen fertilizers application. Values followed by the same letter belong to the same cluster by the Skott-Knott test at 5\% probability. The vertical bars represent the standard error of the averages $(n=3)$. 
According to Taiz and Zieger (2013), nitrogen affects root formation, photosynthesis, photoassimilate production and translocation, and leaf growth rate, with leaf growth primarily affected.

The increase in leaf area with the application of Polyblen Extend ${ }^{\mathbb{B}}$ was $27,8 \%$ in comparison to the treatment with urea application and 75,5\% in relation to the control treatment. According to Dominghetti et al. (2016), nitrogen fertilization and, consequently, the supply of $\mathrm{N}$, promotes the quick growth of the new leaves of the coffee tree.

$\mathrm{N}$ is constituent of many components of the plant cell, such as amino acids and nucleic acids, when lacking causes chlorosis in the older leaves, which later senescence and with this can decrease the leaf area (TAIZ; ZIEGER, 2013).

The accumulation of $\mathrm{N}$ in the dry root mass, in the branches and leaves, together with the total accumulation in the coffee plant, were significantly $(p \leq 0,05)$ influenced by the nitrogen fertilizers and the control treatment (without $\mathrm{N}$ application) (Table2).

The highest values of $\mathrm{N}$ accumulated in the root and the branches occurred with the application of nitrogen fertilizers, with averages values of 89,8 and $370,2 \mathrm{mg} \mathrm{pot}^{-1}$, respectively. In the control treatment, the accumulation of $\mathrm{N}$ in the root $\left(38,1 \mathrm{mg} \mathrm{pot}^{-1}\right)$ and in the branches $(142,9$ $\mathrm{mg} \mathrm{pot}^{-1}$ ) were smaller in comparison to the other treatments.
Polyblen Extend ${ }^{\circledR}$ promoted greater $\mathrm{N}$ accumulation in the leaves $\left(1608,6 \mathrm{mg} \mathrm{pot}^{-1}\right)$ and total in the plant $\left(2168,0 \mathrm{mg} \mathrm{pot}^{-1}\right)$. The highest total accumulation value of $\mathrm{N}\left(2168,0 \mathrm{mg} \mathrm{pot}^{-1}\right)$ occured with the application of Polyblen Extend ${ }^{\mathbb{B}}$. Values followed by the same letter belong to the same cluster revealed a difference of $63 \%$ compared to Urea.

The lowest accumulation of $\mathrm{N}$ in the leaves $\left(382,9 \mathrm{mg} \mathrm{pot}^{-1}\right)$ and in the plant $\left(563.9 \mathrm{mg} \mathrm{pot}^{-1}\right)$ also occurred in the control treatment. The urea showed values of accumulation in the leaves $(912,3$ $\left.\mathrm{mg} \mathrm{pot}^{-1}\right)$ and in the plant $\left(1364,4 \mathrm{mg} \mathrm{pot}^{-1}\right)$ higher than the control, similar to the Ammonium Sulfate $+\mathrm{CaCO}_{2}$ and lower than the other treatments.

Silva et al. (2012) evaluating the accumulation of $\mathrm{N}$ in the dry mass of maize plants after the application of controlled release urea and conventional urea, did not find differences between the nitrogen sources. Valderrama et al. (2014) also did not find differences for $\mathrm{N}$ accumulation in maize leaf after the application of conventional urea and polymer-coated urea in two maize crops.

The photosynthetic rate $\left(\mu \mathrm{mol} \mathrm{CO} \mathrm{m}^{-2} \mathrm{~s}^{-1}\right)$ and the relative index of chlorophyll (RIC) of coffee tree seedlings were influenced $(p \leq 0,05)$ by nitrogen fertilizer application (Figure 4).

The highest value of photosynthetic rate in coffee plants was $2,8 \mu \mathrm{mol} \mathrm{CO} \mathrm{m}^{-2} \mathrm{~s}^{-1}$ with the application of Polyblen Extend ${ }^{2}$. The lowest value of photosynthetic rate was $1,4 \mu \mathrm{mol} \mathrm{CO} \mathrm{m}^{-2}$ $\mathrm{s}^{-1}$ found in the control treatment.

TABLE 2 - N accumulation in root, branches, leaves and total accumulation of $\mathrm{N}$ in the coffee tree after application of nitrogen fertilizer treatments.

\begin{tabular}{ccccc}
\hline Treatments & $\begin{array}{c}\text { N accumulation } \\
\text { in the root }\end{array}$ & $\begin{array}{c}\text { N accumulation in } \\
\text { the branches }\end{array}$ & $\begin{array}{c}\mathrm{N} \text { accumulation in } \\
\text { leaves }\end{array}$ & $\begin{array}{c}\text { Total N } \\
\text { accumulation in } \\
\text { the plant }\end{array}$ \\
\hline Control & $38,1 \mathrm{~b}$ & $142,9 \mathrm{~b}$ & $382,9 \mathrm{e}$ & $563,9 \mathrm{e}$ \\
Urea + Formaldehyde & $90,2 \mathrm{a}$ & $343,8 \mathrm{a}$ & $997,9 \mathrm{~d}$ & $1431,9 \mathrm{~d}$ \\
PolyblenExtend ${ }^{\circledR}$ & $107,8 \mathrm{a}$ & $451,6 \mathrm{a}$ & $1608,6 \mathrm{a}$ & $2168,0 \mathrm{a}$ \\
Polyblen Montanha & $82,3 \mathrm{a}$ & $370,4 \mathrm{a}$ & $1231,4 \mathrm{c}$ & $1684,1 \mathrm{c}$ \\
Urea + Polyurethane & $92,1 \mathrm{a}$ & $339,8 \mathrm{a}$ & $1110,3 \mathrm{c}$ & $1542,23 \mathrm{c}$ \\
Urea + Plastic Resin & $86,8 \mathrm{a}$ & $329,3 \mathrm{a}$ & $1235,0 \mathrm{c}$ & $1651,1 \mathrm{c}$ \\
Urea & $84,4 \mathrm{a}$ & $367,8 \mathrm{a}$ & $912,3 \mathrm{~d}$ & $1364,4 \mathrm{~d}$ \\
Ammonium Sulfate + CaCO & $81,6 \mathrm{a}$ & $359,8 \mathrm{a}$ & $1018,1 \mathrm{~d}$ & $1459,5 \mathrm{~d}$ \\
Ammonium Nitrate & $93,3 \mathrm{a}$ & $399,4 \mathrm{a}$ & $1405,1 \mathrm{~b}$ & $1897,8 \mathrm{~b}$ \\
\hline Average & 84,1 & 344,9 & 1100,2 & 1529,2 \\
\hline Variation coefficient $(\%)$ & 12,9 & 13,8 & 8,8 & 7,7 \\
\hline Values followed by the same letter belong to the same cluster by the Skott-Knott test at 5\% probability.
\end{tabular}




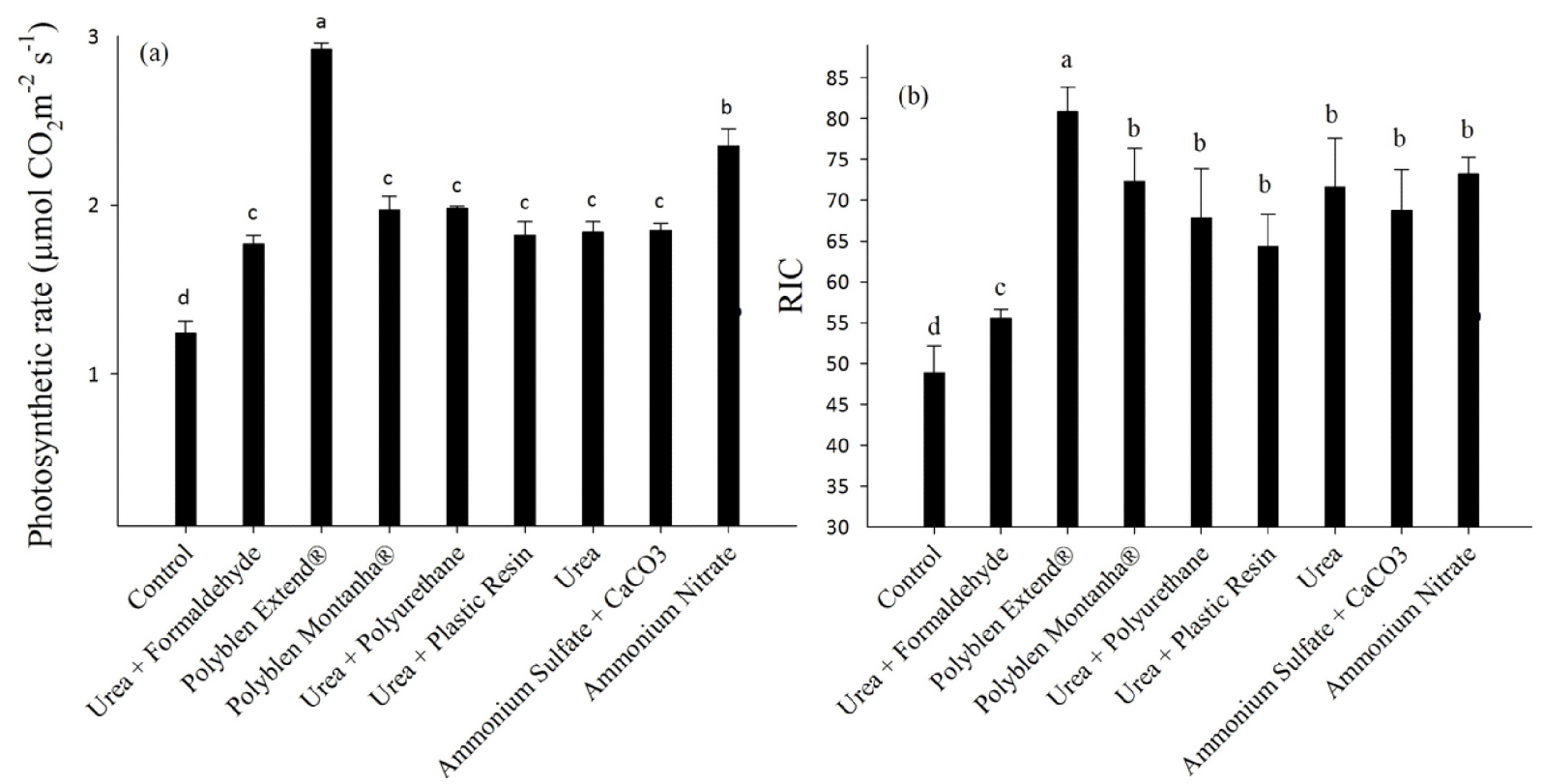

FIGURE 4 - Photosynthetic rate and relative index of chlorophyll (RIC) of coffee plants after application of nitrogen fertilizers. Values followed by the same letter belong to the same cluster by the Skott-Knott test at 5\% probability. The vertical bars represent the standard error of the averages $(\mathrm{n}=3)$.

The higher photosynthetic rate with application of Polyblen Extend ${ }^{\circledR}$, together with the lower values in the control treatment, may be associated to the higher and lower accumulation of $\mathrm{N}$ in the leaves of the coffee tree by these treatments (Table 2). According to Andrade et al. (2015), the photosynthetic rate and the amount of $\mathrm{N}$ in the leaf show a significant positive correlation. According to the authors, $\mathrm{N}$ is a fundamental component for photosynthesis. According to Khamis et al. (1990), $\mathrm{N}$ levels in the leaf below the recommended critical for the plant may reduce the photosynthetic capacity.

The maximum RIC index value was 80,8 with the application of Polyblen Extend ${ }^{\circledR}$. The minimum value was 48,8 in the control treatment. Guimarães et al. (1999), evaluating the RIC in tomato culture, with different doses of $\mathrm{N}$, observed a linear increase of the RIC associated to increase of the doses of N. According to Godoy et al. (2008), the RIC reduces linearly with the reduction of $\mathrm{N}$ doses in the coffee tree. The authors evaluated in the period between flowering and coffee harvest.

Valderrama et al. (2014) evaluating the RIC in maize leaf after nitrogen fertilization with polymer-coated urea and conventional urea, did not find differences between the two sources. The authors evaluated the ICR after maize cultivations.
According to Malavolta et al. (2004), the RIC is based on the correlation between the $\mathrm{N}$ content in the leaf and the chlorophyll content. Torres Netto et al. (2005) and Reis et al. (2006) found positive correlations between the chlorophyll content and the $\mathrm{N}$ content in the coffee leaf in production.

The highest photosynthetic rate and RIC, associated to the highest accumulation of $\mathrm{N}$ in the leaves, and in the whole plant promoted by Polyblen Extend ${ }^{\circledR}$ is associated to the $\mathrm{N}$ supply by this Blend.

The $\mathrm{N}$ from the $30 \%$ urea + NBPT of this Blend may have supplied $\mathrm{N}$ uptake by the coffee tree in the first few days after fertilization, and 70\% urea $+\mathrm{S}^{\circ}+$ polymers provided an adequate supply of $\mathrm{N}$ during the remainder of the experiment.

Ammonium nitrate (soluble), although promoting less loss of $\mathrm{N}_{-} \mathrm{NH}_{3}$ compared to Polyblen Extend ${ }^{\circledR}$ (CHAGAS et al., 2016), may have supplied $\mathrm{N}$ in a large quantity in the first days after each fertilization and provided a smaller amount of $\mathrm{N}$ afterward. Thereby, the residual $\mathrm{N}$ of the fraction with urea $+\mathrm{S}^{\circ}+$ polymers may have been responsible for increasing the accumulation of $\mathrm{N}$ in the leaves, in the whole plant and consequently the photosynthetic rate and the RIC. 
According to Dominghetti et al. (2016), ammonium nitrate promotes the reduction in volatilization losses compared to several fertilizer technologies of increased efficiency found in the Brazilian market. In a study carried out evaluating the losses due to volatilization by nitrogen fertilizers, after fertilization at the dose of 450 $\mathrm{kg}$ ha of $\mathrm{N}$, divided in three applications in the coffee tree in production, the losses were $0,3 \%$ of the $\mathrm{N}$ applied with ammonium nitrate. Whereas, with conventional urea, Urea + Formaldehyde, Urea + Plastic Resin, losses by volatilization were 31,$2 ; 1,1$ and $8,6 \%$ of the $\mathrm{N}$ applied. However, the authors stress that ammonium nitrate does not have the slow or controlled release effect.

In addition, the urea coating with plastic resin, polyurethane, together with urea formaldehyde and ammonium sulfate $+\mathrm{CaCO}_{3}$ may have the N-release time higher than the time used to partition the $\mathrm{N}$ application in this study (50 days). Thereby, the Polyblen Extend ${ }^{\circledR}$ may have promoted greater $\mathrm{N}$ supply during the period of the three fertilizations (150 days), in comparison to the other fertilizers.

Trenkel (2010) reports that the release time of the controlled release fertilizers (Urea + Plastic Resin and Urea + Polyurethane) depends on several factors, including the thickness of the coating and the quality of the coating process by the fertilizer industry. And the release time of the slow release fertilizers such as urea+formaldehyde depends on the degree of polymerization to which the urea has been subjected (YAMAMOTO et al., 2016).

The application of Polyblen Extend ${ }^{\circledR}$ may have offered a better adjustment of the $\mathrm{N}$ released by the fertilizer and the absorption curve of the $\mathrm{N}$ by the coffee tree in the period of conduction of the experiment. According to Noellsch et al. (2009), conventional fertilizer (high solubility in water) can supply the initial demand for $\mathrm{N}$ by the crop and the controlled release fraction over a longer period of time.

PolyblenMontanha $^{\circledR}$, as well as Polyblen Extend $^{\circledR}$, has a soluble fraction (urea + NBPT) however, the controlled release fraction of PolyblenMontanha ${ }^{\circledR}$ (urea $+\mathrm{S}^{\circ}+$ polymers) is able to provide $\mathrm{N}$ for a longer period of time compared to Polyblen Extend ${ }^{\circledR}$ (CHAGAS et al., 2016). This longer period may have promoted lower $\mathrm{N}$ supply during the conduction time of the experiment when compared to the Polyblen Extend ${ }^{\circledR}$.

According to Chagas et al. (2016), the greater thickness of Polyblen Montanha ${ }^{\circledR}$ coating (coating thickness $=87-99 \mu \mathrm{m})$ compared to Polyblen Extend ${ }^{\circledR}$ (coating thickness $=67-68 \mu \mathrm{m}$ ) allows a longer delay in the release of $\mathrm{N}$.

The relative agronomic efficiency index (RAEI) and Agronomic Efficiency (AE) were significantly $(\mathrm{p} \leq 0,05)$ influenced by nitrogen fertilizers (Figures $5 \mathrm{a}$ and $5 \mathrm{~b}$ ).
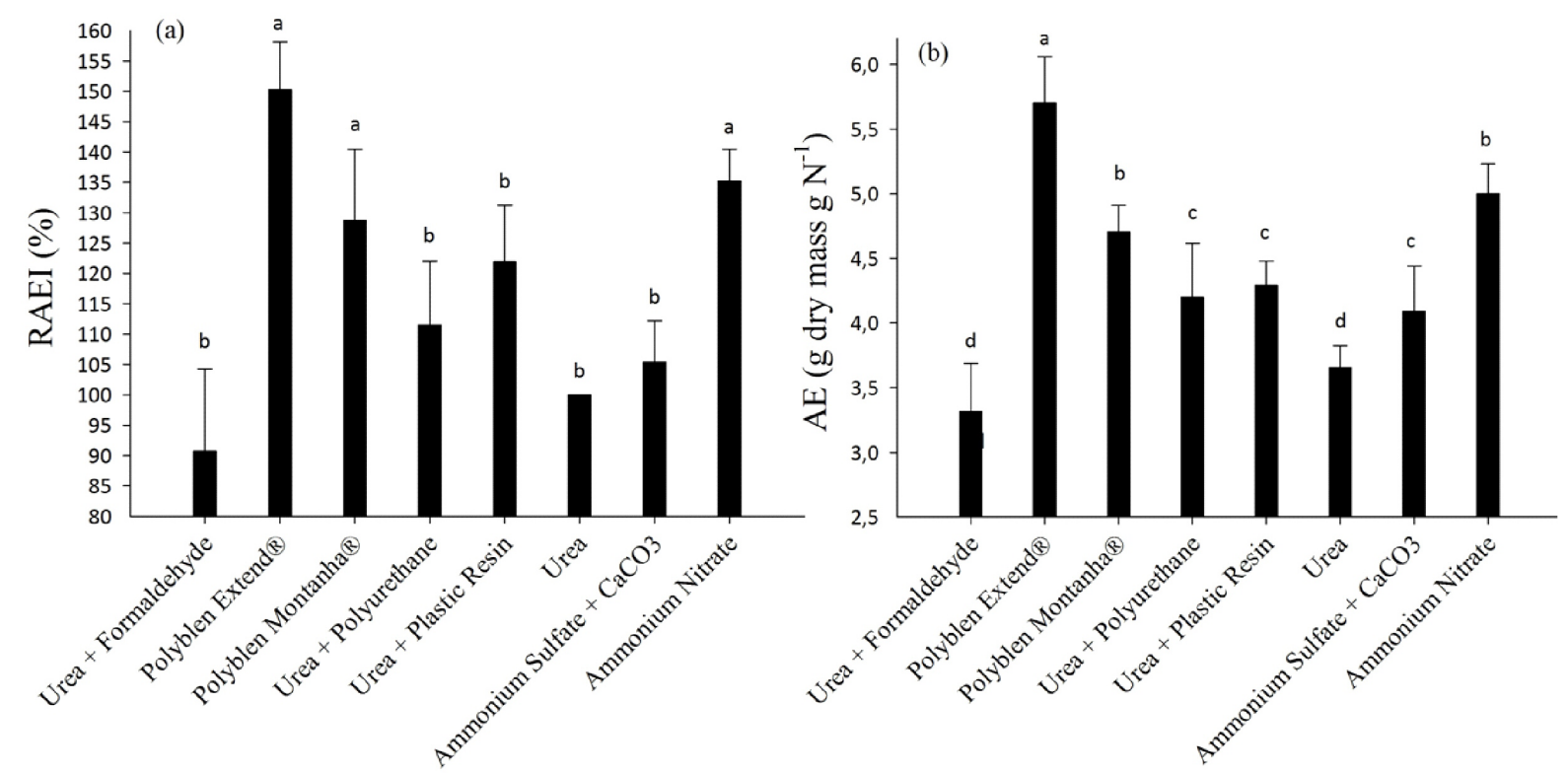

FIGURE 5 - Relative agronomic efficiency index (RAEI) and Agronomic Efficiency (AE) of nitrogen fertilizers after application in the coffee tree. Values followed by the same letter belong to the same cluster by the Skott-Knott test at $5 \%$ probability. The vertical bars represent the standard error of the averages $(n=3)$. 
Polyblen Extend ${ }^{\circledR}(155 \%)$ and Ammonium Nitrate $(136 \%)$ presented the highest values of RAEI. All other fertilizers did not present significant differences $(p \leq 0,05)$ in comparison to urea. The average value of RAEI found for these two sources of $\mathrm{N}$ was $145 \%$, which means that the dry mass production was on average $45 \%$ higher than urea $(100 \%)$.

There are still few studies that evaluate the RAEI after the application of nitrogen fertilizers in the coffee tree. Fontoura and Bayer (2009) evaluated the RAEI for nitrogen sources applied to maize cultivated no-tillage system and found values equal to $108,113,104$ and $122 \%$ for the incorporated urea, ammonium sulfate, ammonium nitrate and urea + NBPT. Also in maize, Zavaschi et al. (2014) found values of $92 \%$ for polymercoated urea, applied at $90 \mathrm{~kg} \mathrm{ha}^{-1}$ of $\mathrm{N}$.

For AE, Urea + Formaldehyde and Urea gave the lowest values, which were 3,6 and 3,3 grams of dry mass per $\mathrm{g}$ of $\mathrm{N}$ applied, respectively. The highest AE value was found with Polyblen Extend $^{\circledR}$ application and was 5,7 grams dry mass per gram of $\mathrm{N}$ applied.

The lowest AE value with Urea + Formaldehyde and conventional urea can be attributed to $\mathrm{N}^{-\mathrm{NH}_{3}}$ losses by volatilization. In a study conducted by Viero et al. (2015), the authors found no reduction in $\mathrm{N}-\mathrm{NH}_{3}$ losses by volatilization with the application of slow release urea when compared to conventional urea.

Polyblen Extend ${ }^{\circledR}$ increased AE by $65 \%$ compared to the average values of Urea + formaldehyde and conventional urea. This reveals that Polyblen Extend ${ }^{\circledR}$ was $65 \%$ more efficient in producing the dry mass of coffee seedlings per unit of $\mathrm{N}$ compared to the application of urea and urea + formaldehyde. In relation to Polyblen Montanha ${ }^{\circledR}$ and Ammonium Nitrate, this increase was $39 \%$.

In a study carried out on maize cultivation, Silva et al. (2012) did not find significant differences in grain yield per unit of $\mathrm{N}$ when using conventional or coated urea, although they observed increased productivity with increasing doses of N. Noellsch et al. (2009), when evaluating the efficiency of $\mathrm{N}$ recovery by maize plants, after the application of Blend (Urea + NBPT and polymer-coated urea), in the ratio $1: 1$ and conventional urea, found the highest values with the application of Blend. $\mathrm{N}$ recovery efficiency was $41 \%$ higher when compared to conventional urea. Both blends and conventional urea have been applied in the coating.

\section{CONCLUSIONS}

The highest values of plant height, total dry mass of plants and leaf area in coffee seedlings were obtained with the application of Polyblen Extend $^{\circledR}$. This Blend also provided greater accumulation of $\mathrm{N}$ in the leaf and whole plant.

The application of Polyblen Extend $^{\circledR}$ promoted greater agronomic efficiency and increased the photosynthetic rate and relative index of chlorophyll in the coffee seedlings at the end of the period of conduction of the experiment.

\section{REFERENCES}

ABALOS, D. et al. Meta-analysis of the effect of urease and nitrification inhibitors on crop productivity and nitrogen use efficiency. Agriculture, Ecosystems \& Environment, Amsterdam, v. 189, p. 136-144, May 2014.

ANDRADE, M. A. F.; RAMOS-CAIRO, P. A.; SANTOS, J. L.. Water relations and photosynthesis of young coffee plants under two water regimes and different $\mathrm{n}$ and $\mathrm{k}$ doses. Agrociencia, San Luis Huexotla, V. 49, n. 2, p. 153-161, Feb. 2015.

AZEEM, B. et al. Review on materials \& methods to produce controlled release coated urea fertilizer. Journal of Controlled Release, Amsterdam, v. 181, p. 11-21, May 2014.

CANCELLIER, E.L. et al. Ammonia volatilization from enhanced-efficiency urea on no-till corn in Brasilian cerrado with improved soil fertility. Ciência e Agrotecnologia, Lavras, v. 40, n. 2, p. 133-144, Mar./ Apr 2016.

CARELLI, M. L. C.; FAHL, J. I.; RAMALHO, J. D. C. Aspects of nitrogen metabolism in coffee plants. Brazilian Journal of Plant Physiology, Londrina, v. 18, n. 1, p. 9-21, Jan./Feb. 2006.

CHAGAS, W. F. T. et al. Ammonia volatilization from blends with stabilized and controlled-released urea in the coffee system. Ciência e Agrotecnologia, Lavras, v. 40, n. 5, p, 497-509, Sept./Oct. 2016.

CHIEN, S.H.; PROCHNOW, L. I.; CANTARELLA, H. Recent developments of fertilizer production and use to increase nutrient efficiency and minimize environmental impacts. In: Bertsch, P. M.; Scow, K. M.; Phillips, R. L.; Wilding, L. P. (Ed.). Advances in Agronomy. Cambridge: Academic press, 2009. Chap. 8, p. 261-316. 
CLEMENTE, F.M.V.T., et al. Faixas críticas de teores foliares de macronutrientes no cafeeiro em pós-plantioprimeiro ano. Coffee Science, Lavras, v. 3, n. 1, p. 4757, Jan./June 2008.

COMISSÃO DE FERTILIDADE DO SOLO DO ESTADO DE MINAS GERAIS, CFSEMG. Recomendações para o uso de corretivos e fertilizantes em Minas Gerais - $5^{\text {a }}$ Aproximação. Viçosa: UFV, 1999. 310p.

DOMINGHETTI, A.W. et al. Nitrogen loss by volatilization of nitrogen fertilizers applied to coffee orchard. Ciência \&Agrotecnologia, Lavras, v. 40, n. 2, p. 173-183, Mar./Apr. 2016.

FAGERIA, N.K.; SANTOS, A.B.; MORAES, M.F. Yield, Potassium Uptake, and Use Efficiency in Upland Rice Genotypes. Communications in Soil Science and Plant Analysis, New York, v. 41, n. 22, p. 26762684, Dec. 2010.

FARIA, L. A. et al. Hygroscopicity and ammonia volatilization losses from nitrogen sources in coated urea. Revista Brasileira de Ciência do Solo, Viçosa, v. 38, n. 3, p. 942-948, May/June. 2014.

FENILLI, T. A. B. et al. Fertilizer ${ }^{15} \mathrm{~N}$ balance in a coffee cropping system: a case study in Brazil. Revista Brasileira de Ciência do Solo, Viçosa, v. 32, n. 4, p. 1459-1469, July/Aug. 2008.

FERREIRA, D. F. Sisvar: a computer statistical analysis system. Ciência e Agrotecnologia, Lavras, v. 35, n. 6, p. 1039-1042, Nov./Dec. 2011.

FONTOURA, S.M.V.; BAYER, C. Adubação nitrogenada para alto rendimento de milho em plantio direto na região centro-sul do Paraná. Revista Brasileira de Ciência do Solo, Viçosa v. 33, n. 6, p. 1721-1732, Nov./Dec. 2009.

FRAZÃO, J. J. et al. Fertilizantes nitrogenados de eficiência aumentada e ureia na cultura do milho. Revista Brasileira de Engenharia Agrícola e Ambiental, Campina Grande, v. 18, n. 12, p. 12621267, Dec. 2014.

GARCIA et al. Efeito da ureia com inibidor de urease no crescimento de mudas de cafeeiro (coffeaarabical.). Coffee Science, Lavras, v. 6, n. 1, p. 1-7, Jan./Apr. 2011.
GODOY, L. J. G. et al. Relative chlorophyll index and nitrogen status of fertigated coffee plants during the crop season. Revista Brasileira de Ciência do Solo, viçosa, v. 32, n. 1, p. 217-226, Jan./Feb. 2008.

GUELFI, D. Fertilizantes Nitrogenados Estabilizados, de Liberação Lenta ou Controlada. Informações Agronômicas, Piracicaba ,n. 157, p. 1 - 14, Mar. 2017.

GUIMARÃES, T.G. et al. Teores de clorofila determinados por medidor portátil e sua relação com as formas de nitrogênio em folhas de tomateiro cultivado em dois tipos de solo. Bragantia, Campinas, v. 58, n. 1, p. 209-216, 1999.

MALAVOLTA, E. et al. Evaluation of nutritional status of the cotton plant with respect to nitrogen. Communications in Soil Science and PlantAnalysis, New York, v. 35, n. 7-8, p. 1007-1019, 2004.

MALAVOLTA, E.; YAMADA, T.; AROALDO, J. Nutrição e adubação do cafeeiro. Piracicaba: Instituto da Potassa e Fosfato, p. 1981. 226.

MARCHESAN, E. et al. Fontes alternativas à ureia no fornecimento de nitrogênio para o arroz irrigado. Ciência Rural, Santa Maria, v. 41, n. 12, p. 2053-2059, Dec. 2011.

MARTINS, I. S.; CAZETTA, J. O.; FUKUDA, A. J. F. Condições, modos de aplicação e doses de ureia revestida por polímeros na cultura do milho. Pesquisa Agropecuária Tropical, Goiânia, v. 44, n. 3, p. 271279, Jul./Sep. 2014.

NAZARENO R.B. et al. Crescimento inicial do cafeeiro Rubi em resposta a doses de nitrogênio, fósforo e potássio e a regimes hídricos. Pesquisa Agropecuária Brasileira, Brasília, v. 38, n. 8, p. 903-910, Aug. 2003.

NOELLSCH, A. J. et al. Corn response to conventional and slow-release nitrogen fertilizers across a claypan landscape. Agronomy Journal, Madison, v. 101, n. 3, p. 607-614, 2009.

PENG, X. et al. A Laboratory Evaluation of Ammonia Volatilization and Nitrate Leaching following Nitrogen Fertilizer Application on a Coarse-Textured Soil. Agronomy Journal, Madison, v. 107, n. 3, p. 871-879, Feb. 2015.

PEREIRA, H. S. et al. Ammonia volatilization of urea in the out-of-season corn. Revista Brasileira de Ciência do Solo, Viçosa, v. 33, n. 6, p. 1685-1694, Nov./Dec. 2009. 
REIS, A.R. et al. Diagnosis of $\mathrm{n}$ requirements for coffee plant using a portable chlorophyllmeter. Bragantia, Campinas, v. 65, n. 1, p. 163-171, 2006.

SANTOS H.G, et al. Sistema brasileiro de classificação de solos. 3.ed. Brasília: Embrapa, 2013. $353 \mathrm{p}$.

SANZ-COBENA, A. et al. Gaseous emissions of $\mathrm{N}_{2} \mathrm{O}$ and $\mathrm{NO}$ and $\mathrm{NO}_{3}$ - leaching from urea applied with urease and nitrification inhibitors to a maize (Zea mays) crop. Agriculture, Ecosystems and Environment, Amsterdam, v. 149, p. 64-73, Mar. 2012.

SILVA, A. de A., et al. Aplicação de diferentes fontes de ureia de liberação gradual na cultura do milho. Bioscience journal. Uberlândia, v. 28, n. 1, p.104-111, 2012.

TAIZ, L.; ZEIGER, E. Fisiologia vegetal. 5.ed. Porto Alegre: Artmed, 2013. 918p.

TEDESCO, M.J. et al. Análise de solo, plantas e outros materiais. 2.ed. Porto Alegre: Universidade Federal do Rio Grande do Sul, 1995.147p. (Boletim Técnico, 5).
TORRES NETO, A. et al. Photosynthetic pigments nitrogen, chlorophyll fluorescense and SPAD-502 readings in coffee leaves. Scientia Horticulturae, Amsterdam, v. 104, n. 2, p. 199-209, Mar. 2005.

TRENKEL, M. E. Slow and controlled-release and stabilized fertilizers: An option for enhancing nutrient use efficiency in agriculture. International Fertilizer Industry Association. Paris, 2010, 167p.

VALDERRAMA, M. et al. Adubação nitrogenada na cultura do milho com ureia revestida por diferentes fontes de polímeros. Semina: Ciências Agrárias, Londrina, v. 35, n. 2, p. 659-670, Mar./April 2014.

VIERO, F.et al. Management of Irrigation and Nitrogen Fertilizers To Reduce Ammonia Volatilization. Revista Brasileira de Ciência do Solo, Viçosa, v. 39, n. 6, p. 1737-1743, Nov./Dec. 2015.

YAMAMOTO, C.F. et al. Slow release fertilizar based on urea/urea-formaldehyde polymer nanocomposites. Chemical Engineering Journal, Amsterdam v. 287, n. 10, p. 390-397, Mar. 2016.

ZAVASCHI, E. et al. Ammonia volatilization and yield components after application of polymer-coated urea to maize. Revista Brasileira de Ciência do Solo, Viçosa, v. 38, n. 4, p. 1200-1206, Jul./Aug. 2014. 